\title{
Measuring and profiling financial literacy in South Africa
}

\section{Authors:}

Elizabeth L. Nanziri ${ }^{1}$

Murray Leibbrandt ${ }^{1}$ (D)

\section{Affiliations:}

${ }^{1}$ Southern Africa Labour and Development Research Unit, School of Economics, University of Cape Town,

South Africa

\section{Corresponding author:}

Elizabeth Nanziri,

elizabethlwanga.nanziri@

uct.ac.za

Dates:

Received: 06 Aug. 2016

Accepted: 26 Feb. 2018

Published: 28 May 2018

How to cite this article:

Nanziri, E.L., \& Leibbrandt,

M., 2018, 'Measuring and

profiling financial literacy in

South Africa', South African

Journal of Economic and

Management Sciences 21(1),

a1645. https://doi.org/

10.4102/sajems.v21i1.1645

\section{Copyright:}

(C) 2018. The Authors. Licensee: AOSIS. This work

is licensed under the

Creative Commons

Attribution License.
Read online:

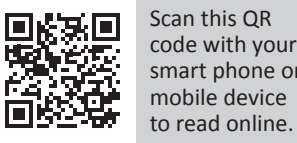

Background: Microeconomic theories of financial behaviour tend to assume that consumers possess financial skills necessary to undertake related financial decisions.

Aim and setting: We investigated this assumption by exploring the distribution of financial literacy among South Africans.

Method: In the absence of a standard measure, a financial literacy index was constructed for the country using data collected on attitudes (towards), access to and use of financial services over the period 2005-2009. In a multivariate regression analysis, we used the index to examine the extent to which differences in financial literacy correlate with demographic and economic characteristics.

Results: The index revealed substantial variation in financial literacy by age, education, province and race. Overall, demographic characteristics contributed up to $10 \%$ of the financial literacy differences among individuals in South Africa.

Conclusion: These results can be used to guide policy makers where to place more emphasis in terms of financial education for South Africans.

\section{Introduction}

There is increasing focus on making formal financial services accessible to all members of society. ${ }^{1}$ At the same time, the financial sector is becoming innovative with products that might be considered complex and sophisticated for potential consumers. These developments place substantial demand on the individual in terms of financial decision making and management. In microeconomics, the consumption-saving trade-off assumes a rational and well-informed consumer who is capable of accumulating savings in times of high income and spending savings when income is low. This is in the framework of the life-cycle hypothesis advanced by Friedman (1957) and Modigliani and Brumberg (1954). This consumption smoothing over periods, whether two-period or in a dynamic multi-period life cycle, assumes that the individuals have perfect foresight. That is, that they are able to predict the economic environment and subsequently undertake complex calculations on interest rates and discount rates in order to invest (Lusardi \& Mitchell 2014). If such a model is extended to incorporate concerns such as credit constraints, and the risk of death of economic agents, then the financial skills requirement becomes even more demanding (see for instance Gorbachev \& Luengo-Prado 2016). Rational behaviour is questionable, however, from the behavioural finance perspective. ${ }^{2}$ Moreover, external factors, such as the economic environment and availability of social welfare systems, plus risk preferences of individuals have implications for the acquisition of financial skills necessary for financial decision making.

The theoretical underpinnings of financial literacy are mixed. Development psychology theories (psychoanalysis, psychosocial and cognitive psychology) posit that financial literacy is not learned but is shaped by one's upbringing (which shapes one's personality), emotions and interactions in life (Erikson 1980; King \& Levine 1993). The exchange theory, on the other hand, argues that the level of financial literacy will depend on the level of knowledge exchange and interactions

\footnotetext{
1.See for instance, the World Bank initiative on Universal Financial Access (UFA), Financial Inclusion 2020 (FI2020) and Alliance for
} Financial Inclusion, http://www.afi.ors

2.See for instance Muradoglu and Harvey (2012), Garcia (2013)

Note: This article is partially based on the authors' Working Paper: Series Number 171, 'Measuring and profiling financial literacy in South Africa' at Southern Africa Labour and Development Research Unit, University of Cape Town, South Africa, by Elizabeth L. Nanziri and Murray Leibbrandt, available here: http://opensaldru.uct.ac.za/bitstream/handle/11090/820/2016_171_Saldruwp.pdf 
among individuals. Knowledge diffusion is therefore more likely in high-density population areas (see Robson \& Labner 2006). Implicit in this is the learning process, either from colleagues or on the job, while engaging in day-to-day financial activities. In the spirit of the learning theory (see Goldhaber 2000; Pavlov 1960), financial literacy is linked to habit formation, whereby reinforcement or punishment determines continuity of action. An individual can therefore learn and master financial skills if he is positively rewarded. All these arguments can be summed up in the capability theory advanced by Nussbaum and Sen (1993), that an individual's capability is a combination of personal capabilities (e.g. cognitive ability, personality traits) and external factors. The absence of external support can inhibit individuals' financial performance even when they possess the relevant skills.

Empirical work guided by these theories and summarised in Lusardi and Mitchell (2014) shows that few individuals possess the necessary financial skills required to make decisions to save or invest and consume between periods. However, the definition of what constitutes financial skills, often referred to as financial literacy, is not standardised, leading to varied measurement of the same concept. Huston (2010) describes financial literacy as a form of literacy that relates to one's proficiency in making financial decisions. So, how proficient are individuals to draw up saving and spending plans? How is this proficiency distributed in a population?

To answer these questions, we constructed a financial literacy index for South Africa for the period 2005-2009. Defining financial literacy as a composite of two domains, financial knowledge and financial capability, questions that fall in each of those domains were identified. These questions were selected from the FinScope ${ }^{3}$ surveys conducted on attitudes towards, and use of, financial services. We then used the Principle Component Approach to combine responses to these questions to obtain a score for each individual. This score was then used to investigate financial literacy differences across categories of the population and across regions.

The index revealed substantial variation in the financial literacy of South Africans. The national average is 48.4 on a scale that ranges between 0 and 100. Below average financial literacy is found among black South Africans, women, the young, individuals with less than high school education, with a low income, and those living in the Eastern Cape province. Overall, demographic characteristics account for up to $10 \%$ variation in financial literacy while geographical location only explains an additional $0.7 \%$ of the variation. This implies that provincial differences in financial literacy are a result of demographic and economic differences between provinces.

\section{Literature review}

The pioneering work of Lusardi and Mitchell (2007:36) suggests a simple definition of financial literacy as the knowledge of a few but fundamental financial concepts'. In a series of studies conducted in 14 countries, ${ }^{4}$ the term is defined explicitly as 'the possession of financial knowledge on interest rates, inflation, and risk diversifications, and numeracy skills' (Xu \& Zia 2012:4). In subsequent studies, and borrowing from capability theory, financial literacy has been defined more comprehensively to include both possession of knowledge and actions that accompany that knowledge as summarised in Appendix A1. In the wake of the global financial crisis of 2008, the Organisation for Economic Cooperation and Development (OECD) suggested that the concept should be broadened to constitute:

... consumers' or investors' understanding of financial facts and concepts, and their ability to appreciate financial risks and opportunities to make informed choices, to know where to go for help and to take other effective actions to improve their financial well-being. (Miller et al., 2009:2)

Following from the above definitions, measures have included setting numeric questions and either counting the proportion of the population that gives correct responses or weighting the responses to form a financial literacy index. ${ }^{5}$ Such an index is then used to investigate the distribution of the scores in a particular country as being synonymous with the level of financial literacy. Some patterns have emerged.

Using the proportion of correct answers to a set of three questions, Lusardi and Mitchell (2007) found that in the USA financial literacy is low among women, the young and the old. They also found that financial literacy is positively associated with income and education attainment. However, in Germany, Bucher-Koenen and Lusardi (2011) found no significant difference between the financial literacy levels of men and women using the same measure. They report, however, a stark difference between the financial literacy of individuals in the eastern and western regions of the country. A similar regional finding is reported by Fornero and Monticone (2011) between the northern and southern regions of Italy, and in the northern half of the USA compared to states located in the eastern and southern parts (Bumcrot, Lin \& Lusardi 2011). In the USA, the regional differences are reported to be correlated with a state's poverty level. Klapper and Panos (2011) attribute the higher financial literacy levels exhibited by urban dwellers in Russia compared to their rural counterparts to the high number of interactions and hence knowledge diffusion in areas of high population density. Racial differences are also evident. For example, Crossan, Feslier and Hurnard (2011) found that the Maori group in New Zealand have low levels of financial literacy, as do Hispanics in the USA (Lusardi \& Mitchell 2011b). Both these racial groups are part of the minority groups in these countries.

In the context of middle- to-low income economies, financial literacy is defined in terms of financial outcomes and linked to holding a bank account (see $\mathrm{Xu}$ and Zia 2012). This follows arguments by researchers like Dragan (2011) and

4.Azerbaijan, Chile, Germany, India, Indonesia, Italy, Japan, Netherlands, New Zealand Romania, Russia, Sweden, USA, and West Bank and Gaza.

5.See Hung et al. (2009) for a summary of the measures. 
Cole, Sampson and Zia (2011) that individuals will only demand financial services and products if they have enough knowledge about them. Indeed, the FinScope surveys reported that one of the reasons why respondents in Malawi and Tanzania did not have bank accounts is that they had never heard of a savings account or that they did not know how to open one. Lack of understanding of insurance products leading to low take-up has also been reported in countries like Guatemala (Cohen \& Young 2007), rural India (Gine et al. 2010) and Vietnam (Tran \& Yun 2004). But an outcome-based measure might lead to either an upward or a downward bias owing to selection into participating in the formal financial sector or owing to capturing the extent of financial access. Indeed, in the wake of broad-based financial access, it is highly likely that individuals will hold products without necessarily understanding their functionality.

It is important to note that the lack of standardisation in the definition of financial literacy, and the subsequently different measurement of the concept, make comparisons across countries problematic. Hence the need for more countryspecific studies. South Africa presents an interesting case study, in part owing to the fact that no rigorous empirical work has been undertaken following financial sector transformation towards broad-based financial access in the country in the early 1990s. Secondly, the country exhibits both high-income and low-income country characteristics, which poses the challenge of which measure of financial proficiency to adopt. In the section that follows, the methodological approach to addressing this research gap is outlined.

\section{Data and methodology}

We adopted a combination of the definitions of financial literacy of Atkinson et al. (2007) and the OECD (2009) to align it to South Africa's financial sector characteristics. There are two financial literacy domains: financial knowledge and financial capability. Questions aligned to these domains were identified, the individual responses computed and the average scores cross-tabulated with demographic characteristics of the population. Principal component analysis (PCA) was then used to construct a composite index from the two domains as advocated by the OECD (2009). This allows for the profiling of the population using the average score of the index. Finally, regression analysis was used to investigate the determinants of financial literacy.

Regarding financial knowledge, the emphasis is on the understanding of financial concepts, financial institutions and financial regulations. In the South African context, such data have been collected in the nationally representative FinScope surveys that have been conducted regularly since 2002. ${ }^{6}$ These data are collected using face-to-face interviews with individuals. We made use of the data collected on attitudes (towards), access to and use of financial services over the period 2005-2009.

6.For more detail on these surveys, see FinScope Financial Access Surveys: https:// www.finmark.org.za/finscope/
In the FinScope surveys, respondents were asked about their knowledge and understanding of words or phrases in each of the above subcategories (financial concepts, institutions and regulations). Responses were then coded as: $3=$ Heard of the word/phrase and know what it means; $2=$ Heard of the word / phrase but do not know what it means; 1 = Never heard of this word/phrase. Since this domain tests whether one understands the terms and concepts presented, individuals who had heard of but did not understand these concepts were considered to be in the same category as those who had never heard of them. Following this argument, variables were re-coded to equal to one if a respondent had heard of and understood a particular financial term/phrase, and zero otherwise. In other questions, respondents were instead asked which financial areas they needed financial education on. This was considered to be a self-reported financial knowledge gap which was coded as a binary variable with $1=$ yes (if a respondent chose a particular financial term/concept/phrase) and zero otherwise. Subsequently, the coding of such questions was reversed for consistency. The following phrases from the surveys were considered:

- Knowledge and understanding of bad debt

- Knowledge and understanding of the National Credit Act (NCA)

- Knowledge and understanding of credit bureaus

- Knowledge of compounding interest (saving small amounts and investing overtime)

- Gap variables:

- Use of financial services and products - combining questions that related to selecting savings and investment products, insuring household contents and how to draw up and manage a budget (deals with day-to-day financial discipline)

- Knowledge of life insurance

- Knowledge of how to find out about one's credit worthiness

- How interest rates work and are calculated

- Trust in banks - this question was frequently phrased as 'You do not trust banks'

According to Kempson and Moore (2005), knowledge of financial terms, regulations and institutions is necessary but not sufficient to measure the financial literacy levels of individuals, hence the financial capability domain. Financial capability is said to incorporate knowledge, skills and behaviour in five areas. These include: making ends meet; planning ahead; choosing financial products and services; staying informed; and keeping track of one's finances. As is evident, the knowledge areas feed directly into this domain. The dataset used provides a range of questions corresponding to these areas. Respondents were presented with a range of statements and their responses were recorded as 'agree' (coded as 1), 'disagree' (coded as 0) or 'do not know' (also coded as 0 ). Selecting only questions that were consistent across surveys resulted in the following seven statements to be considered for our study:

- You try to save regularly.

- You are saving for something specific. 
- You are worried you will not have enough for retirement.

- You go without basics so as to save.

- You love spending even if you have to borrow to do so.

- You read the financial pages of newspapers and magazines.

- When it comes to finances you prefer to speak to friends or family for advice.

In our approach, we do not incorporate the holding of any product as a variable in the capability domain. Product holding can be a consequence of literacy or a reflection of financial access policy. The latter is a plausible argument, given that post-apartheid South African government undertook financial sector transformations in the form of broad-based financial access.

Responses to questions in the two domains of financial knowledge and financial capability were combined to construct a composite financial literacy index from the pooled surveys (2005-2009). The composite financial literacy index was thus constructed according to the expression below:

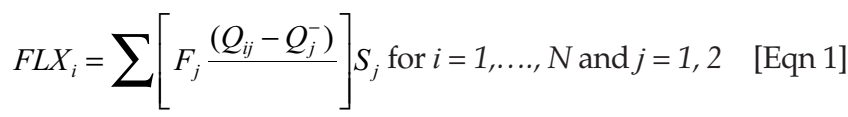

where $F L X_{i}$ is the financial literacy score for individual $i, Q_{i j}$ is the score in domain $j$ for individual $i, Q_{j}^{-}$is the sample mean, $S_{j}$ is the sample standard deviation and $F_{j}$ is the eigenvector of the first principal component weights. The scores were re-scaled through a linear transformation for ease of interpretation. Analogous to socio-economic status indices, the higher the score, the higher the implied financial literacy level of the individual (see Vyas \& Kumaranayake 2006). For example, on a 0-100 index, an individual scoring zero has a financial literacy of zero (financially illiterate) while a score of 100 is equivalent to a financial literacy level of 100 (financially sophisticated). Thus the financial literacy profile of South Africans is obtained by comparing the mean financial literacy scores across the socio-economic and demographic characteristics of individuals in the sample, and weighting the data for national representativeness.

\section{Summary of the data}

The weighted descriptive statistics are provided in Table 1. The pooled data showed a slightly higher proportion of women $(52 \%)$ compared to men $(48 \%)$. Black people made up almost $80 \%$ while the rest of the population groups made up the remaining $20 \%$. The majority of the sample had some high school education $(40 \%)$ and was $18-29$ years old, while the oldest respondent was 92 years old. More respondents were interviewed in urban areas (57\%), with a regional distribution in favour of Gauteng, KwaZuluNatal, the Eastern Cape and the Western Cape. Twentyseven per cent of the respondents were formally employed, followed by pensioners and the self-employed. About $60 \%$ of the sample earned a personal monthly income of less than $\mathrm{R} 1000$, with $16.5 \%$ grant recipients, and in some cases individuals held more than one job. The average household size was four. The data were weighted using the Statistics South Africa weights as benchmarks. This sample is therefore nationally representative of the major population groups of the country and is balanced in terms of gender and region.

Table 2 shows the proportion of affirmative responses to the domain questions. Panel A shows that about $44 \%$ of the respondents reported knowledge of 'bad debt', 11\% knew about credit bureaus, and only $2 \%$ knew about the National Credit Act (NCA) even though these terms are closely related. ${ }^{7}$ Knowledge of budgeting and interest rates was low, and respondents admitted to not trusting banks. About $24 \%$ claimed knowledge of how to use savings, insurance and investment products. On average, respondents scored five out of nine points (see the sample average shown in Appendix 2), while almost one-third scored between zero and four points.

The mean score varies across the sample. As reported in Appendix 2, it is higher for men than for women, and the white subpopulation scored the highest among the population groups (7 points), followed by the Indian subgroup (6.4 points), the mixed race subgroup (5.7 points) and the black subgroup (4.7 points). There is a slow but steady rise in score with increasing age, tapering off after 59 years. Individuals with less than matric scored below average while those with matric level of education and above scored above average; however, students scored far lower than those in other occupation categories. Grant recipients answered up to four questions correctly, while scores increased with increasing personal income. As expected, urban dwellers scored above average and higher than their rural counterparts, while individuals who were participating in the financial sector (currently banking) scored better than those who had never banked over the period.

In the capability domain, $47 \%$ of our sample claimed to save regularly (Table 2 [Panel B]), yet only 19\% alluded to spending wisely, and $21 \%$ said that they were not worried about having enough for retirement. The majority of the respondents scored between two and three points, with just about $1 \%$ scoring all or no points. Overall, the average score for the sample is three out of seven points. Decomposing the mean score by socio-economic and demographic characteristics, a pattern similar to the one in the knowledge domain emerges. That is, scores are lower than average for black South Africans, for women, for individuals with less than matric level of education and for rural dwellers. (These results are reported in Appendix 3.)

A key element in this domain is the source of financial information used by consumers. ${ }^{8}$ The majority of the respondents reported using 'friends and family' as a source

7.The NCA regulates formal credit transactions and it requires lenders to be registered but knowledge of 'bad debt' could imply a bad experience with credit either from formal or from informal sources.

8.For example, Lusardi et al. (2009) found a significant correlation between peers and communities as a source of information and higher levels of financial literacy among youths. 
TABLE 1: Summary statistics for the data (2005-2009).

\begin{tabular}{|c|c|c|c|c|c|c|c|}
\hline Category & Variable & 2005 & 2006 & 2007 & 2008 & 2009 & Pooled \\
\hline $\bar{N}$ & - & 3568 & 3643 & 3675 & 3329 & 3575 & 18694 \\
\hline \multirow[t]{2}{*}{ Gender } & Male & 47.6 & 48.8 & 46.8 & 47.0 & 47.6 & 47.9 \\
\hline & Female & 52.4 & 51.2 & 53.2 & 53.0 & 52.4 & 52.1 \\
\hline \multirow[t]{4}{*}{ Race } & Black people & 79.7 & 79.0 & 78.7 & 79.7 & 79.5 & 79.3 \\
\hline & Mixed race people & 9.1 & 9.5 & 8.6 & 9.1 & 8.6 & 9.0 \\
\hline & Indian people & 2.1 & 2.2 & 2.1 & 2.0 & 2.1 & 2.1 \\
\hline & White people & 9.1 & 9.3 & 10.6 & 9.2 & 9.8 & 9.6 \\
\hline \multirow[t]{4}{*}{ Education } & No education & 2.8 & 5.9 & 3.8 & 1.3 & 2.3 & 3.2 \\
\hline & Primary school & 17.1 & 16.7 & 12.1 & 10.7 & 10.7 & 13.5 \\
\hline & High school & 67.1 & 64.8 & 70.1 & 72.0 & 72.2 & 69.2 \\
\hline & Post high school & 13.0 & 12.6 & 13.9 & 16.0 & 14.8 & 14.1 \\
\hline \multirow[t]{4}{*}{ Age category } & $18-29$ years & 37.9 & 34.8 & 38.4 & 37.2 & 39.0 & 38.1 \\
\hline & $30-44$ years & 31.8 & 34.6 & 38.4 & 40.1 & 37.9 & 35.7 \\
\hline & $45-59$ years & 17.9 & 19.0 & 11.4 & 11.9 & 11.9 & 14.2 \\
\hline & $60+$ years & 12.3 & 11.6 & 11.8 & 10.8 & 11.3 & 12.0 \\
\hline \multirow[t]{9}{*}{ Province } & Eastern Cape & 14.1 & 13.9 & 12.3 & 13.0 & 12.6 & 13.5 \\
\hline & Free State & 6.6 & 6.8 & 5.6 & 5.1 & 5.7 & 6.0 \\
\hline & Gauteng & 21.8 & 21.9 & 24.6 & 23.6 & 22.1 & 22.1 \\
\hline & KwaZulu-Natal & 19.2 & 19.0 & 20.6 & 20.4 & 19.3 & 19.9 \\
\hline & Limpopo & 10.9 & 10.3 & 9.4 & 8.5 & 9.4 & 10.2 \\
\hline & Mpumalanga & 6.7 & 7.0 & 7.5 & 6.9 & 7.2 & 6.9 \\
\hline & Northern Cape & 1.9 & 2.1 & 2.1 & 2.3 & 2.3 & 2.1 \\
\hline & North West & 8.4 & 8.1 & 6.9 & 7.5 & 9.3 & 8.1 \\
\hline & Western Cape & 10.4 & 10.9 & 10.9 & 12.8 & 12.0 & 11.2 \\
\hline \multirow[t]{2}{*}{ Geo-area } & Urban & 53.1 & 61.2 & 63.4 & 66.3 & 64.9 & 57.0 \\
\hline & Rural & 46.9 & 38.8 & 36.6 & 33.7 & 35.1 & 43.0 \\
\hline \multirow[t]{4}{*}{ Marital status } & Single & 47.3 & 48.7 & 51.1 & 57.0 & 58.5 & 53.2 \\
\hline & Divorced & 2.4 & 2.8 & 1.8 & 2.5 & 1.7 & 2.1 \\
\hline & Widowed & 8.7 & 7.1 & 6.2 & 5.4 & 5.7 & 6.8 \\
\hline & Married & 41.6 & 41.4 & 40.9 & 35.2 & 34.1 & 37.8 \\
\hline \multirow[t]{3}{*}{ Source of money } & Formal & 11.4 & 21.6 & 28.1 & 35.9 & 29.8 & 23.9 \\
\hline & Informal & 21.0 & 39.3 & 34.4 & 33.4 & 36.4 & 32.9 \\
\hline & Grant & 8.3 & 19.9 & 19.5 & 16.1 & 15.1 & 16.6 \\
\hline \multirow{5}{*}{$\begin{array}{l}\text { Personal monthly } \\
\text { income }\end{array}$} & Up to R999 & 67.3 & 65.4 & 61.0 & 50.0 & 49.0 & 60.7 \\
\hline & R1000-5999 & 25.9 & 27.6 & 32.9 & 40.6 & 41.9 & 32.2 \\
\hline & R6000-9999 & 3.5 & 4.1 & 3.4 & 5.7 & 5.6 & 4.1 \\
\hline & R10 000-24999 & 2.9 & 2.7 & 2.5 & 3.3 & 3.2 & 2.7 \\
\hline & R25 000+ & 0.3 & 0.3 & 0.2 & 0.4 & 0.4 & 0.3 \\
\hline \multirow[t]{7}{*}{ Employment status } & Pensioner & 13.5 & 12.2 & 10.9 & 9.6 & 10.6 & 11.8 \\
\hline & Formal employee & 25.5 & 26.7 & 28.4 & 35.5 & 30.2 & 27.7 \\
\hline & Housewife & 4.1 & 3.7 & 3.5 & 3.6 & 3.8 & 3.7 \\
\hline & Student & 9.3 & 6.7 & 8.7 & 8.7 & 8.6 & 8.7 \\
\hline & Informally employed & 3.9 & 8.9 & 8.5 & 11.4 & 8.8 & 8.2 \\
\hline & Self-employed & 31.3 & 7.3 & 8.3 & 6.7 & 7.1 & 11.8 \\
\hline & Unemployed & 11.1 & 33.8 & 30.3 & 24.1 & 30.6 & 27.3 \\
\hline
\end{tabular}

Note: The table shows the structure of the cross-sections and the pooled dataset, weighted to be nationally representative. Income is in 2009 rand terms. Wilk's lambda: $0.4235, F(176.0,62397.7)=$ 85.23, Prob $>F=0.0000$ a

of financial information, while 'financial pages' are rarely used (Table 2 [Panel C]).

Notice that if only one domain was to be considered as a measure of financial literacy (see Hung, Parker \& Yoong 2009, for example), South Africans would be more financially literate using the knowledge domain than using the capability domain, going by the average score in each of these domains. Similarly, using the 'Big Three' as in several studies (see Xu \& Zia 2012) would make the picture even worse, since only $1.8 \%$ of the sample reported knowledge of the interest rate concept while $23.9 \%$ reported knowledge of saving and investment (Table 2), which is akin to the concept of a compounding interest rate.

\section{Results}

\section{Profile of financial literacy}

The constructed financial literacy index combines the domains into a score that ranges between 0 and 100, with a mean of 48.4 (Figure 1). Overall, the index follows a normal distribution, with the majority of South Africans around the country's mean. But the densities become flatter and fatter for any shift to the right of the national mean, implying that there are few financially literate individuals, and that those who are literate had very high scores. Appendix 4 shows the density plots for within in-group differences in financial literacy by various 
TABLE 2: Positive responses for financial literacy domain questions.

\begin{tabular}{lcc}
\hline Panel & Number of respondents & $\%$ \\
\hline A: Financial knowledge & 8162 & 43.61 \\
Bad debt & 434 & 2.32 \\
National Credit Act & 2029 & 10.84 \\
Credit bureaus & 4481 & 23.94 \\
Saving and investing makes you secure & 2652 & 14.17 \\
How to use services and products & 347 & 1.85 \\
Interest rates & 135 & 0.72 \\
Drawing-up and managing a budget & 36 & 0.19 \\
Life insurance & 25 & 0.13 \\
How to check creditworthiness & 154 & 0.82 \\
Trust banks & 263 & 1.40 \\
None & & \\
B: Financial capability & 8806 & 47.05 \\
Save regularly & 734 & 3.92 \\
Save for specifics & 820 & 4.38 \\
Save at all costs & 3972 & 21.22 \\
Have enough for retirement & 3640 & 19.45 \\
Spend wisely & & \\
C: Sources of financial information & 11466 & 61.26 \\
Friends and family & 1225 & 6.55 \\
Financial pages & 6026 & 32.2 \\
Other (financial advisers, moneylenders, & & \\
churches, employers, schools, community) & & \\
\hline
\end{tabular}

Note: The table shows the proportion of respondents who scored a point for a positive response to a particular question. 'None' implies that these respondents did not respond to response to a particular question. None implies that these respondents did not respond to Data is weighted to be nationally representative. The weights are benchmarked against Statistics South Africa weights.

categories. ${ }^{9}$ There is no visible difference in the distribution of financial literacy scores by gender, age group and geoarea. There are, however, substantial differences in the distribution by education, marital status, personal income and race. Higher income and education levels are associated with a shift to the right of the country's mean, reflecting above average financial literacy. The distribution for white and Asian people is also skewed to the right, while distribution for black and mixed race people is skewed to the left.

To obtain a clearer view of the distribution, the with-in categories mean scores are provided in Figure 1. Lower than average levels of financial literacy are evident among women, black South Africans, those with less than matric (high school), and those in the age group 18-29 years. This pattern is similar to those reported in studies for uppermiddle income economies such as the USA, Europe, Japan and New Zealand, as well as for low-middle income countries such as India, Indonesia, West Bank and Gaza (see Xu \& Zia 2012 for a summary). Lusardi, Mitchell and Curto (2009) and Johnson and Sherraden (2006) found similarly low levels of financial literacy among youths in the USA.

Financial literacy is high at higher levels of education and for individuals older than 30 years of age, tapering off slightly at 60 years. This finding follows the inverted U-shape reported by Lusardi and Mitchell (2011a), Xu and

\footnotetext{
9.All data are weighted by weights benchmarked against Statistics South Africa weights to make the statistics nationally representative. See Appendix 5 for the full set of decomposition results.
}

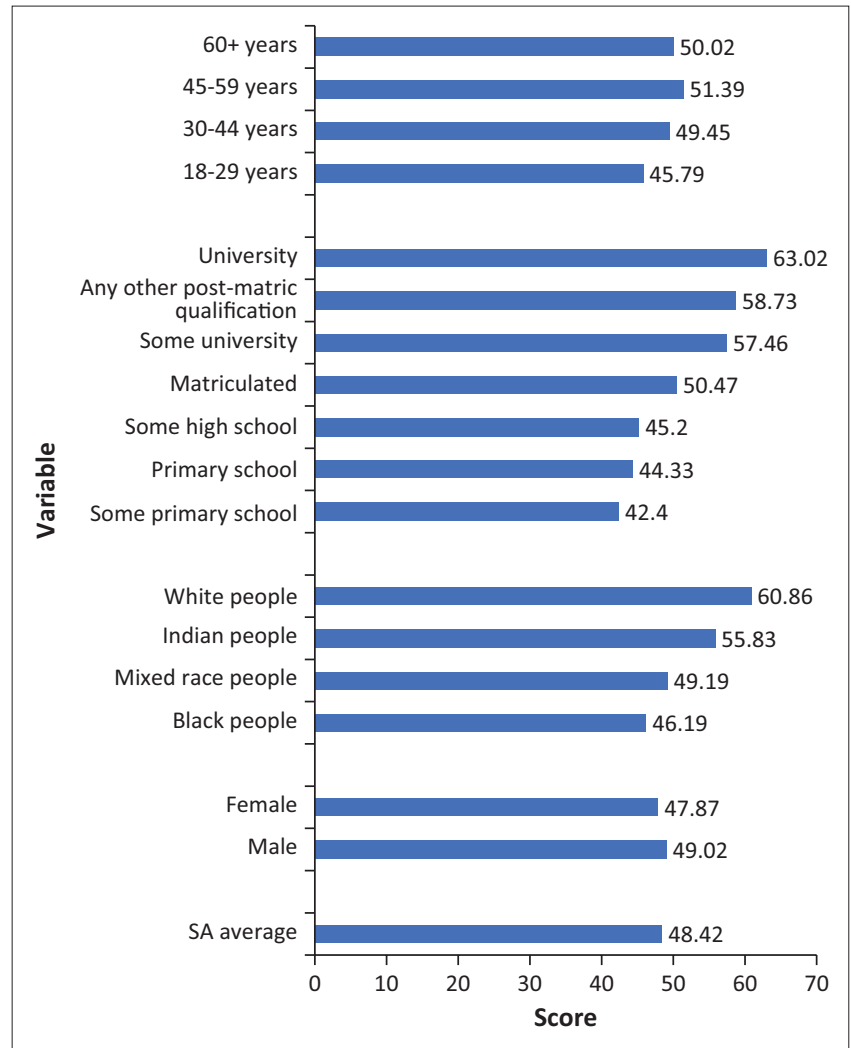

Note: The figure shows the mean financial literacy score in the age, gender, education and race categories. The data is weighted to be nationally representative. Weights are benchmarked against Statistics South Africa weights.

FIGURE 1: Financial literacy by age, education, gender and race.

Zia (2012) and Jappelli and Padula (2011). According to Jappelli and Padula (2011), this is evidence of a decline in cognitive ability in the latter years of an individual's life.

The index values are disaggregated further by economic variables such as major sources of money, occupation and income categories (Figure 2). On average, the formally employed, self-employed and pensioners have above average financial literacy, while students and the unemployed score the lowest in the occupation category. Lower levels of financial literacy among students have also been reported by Beal and Delpachitra (2003) among Australian university students, Markow and Bagnaschi (2005), Mandell (1997), Lusardi et al. (2009), and Chen and Volpe (2002) among college students and young adults. Individuals receiving money from formal sources have higher scores while recipients of grants and income from informal sources have below average scores. This difference could be owing to the requirement by formal employers that employees use formal financial mechanisms to receive salaries and other employment benefits, which in turn requires financial proficiency. It is worth noting that social grants in South Africa are targeted at the poor and are means tested. ${ }^{10}$ This highlights the low financial literacy pattern observed among grant recipients. This is problematic as grant recipients are often offered many financial

10.Grants include child support, foster care support, care dependency, old age support, disability, war veteran, social relief of distress, and grant-in-aid. There are as many as 8 million grant recipients on average per year (www.sassa. gov.za). 


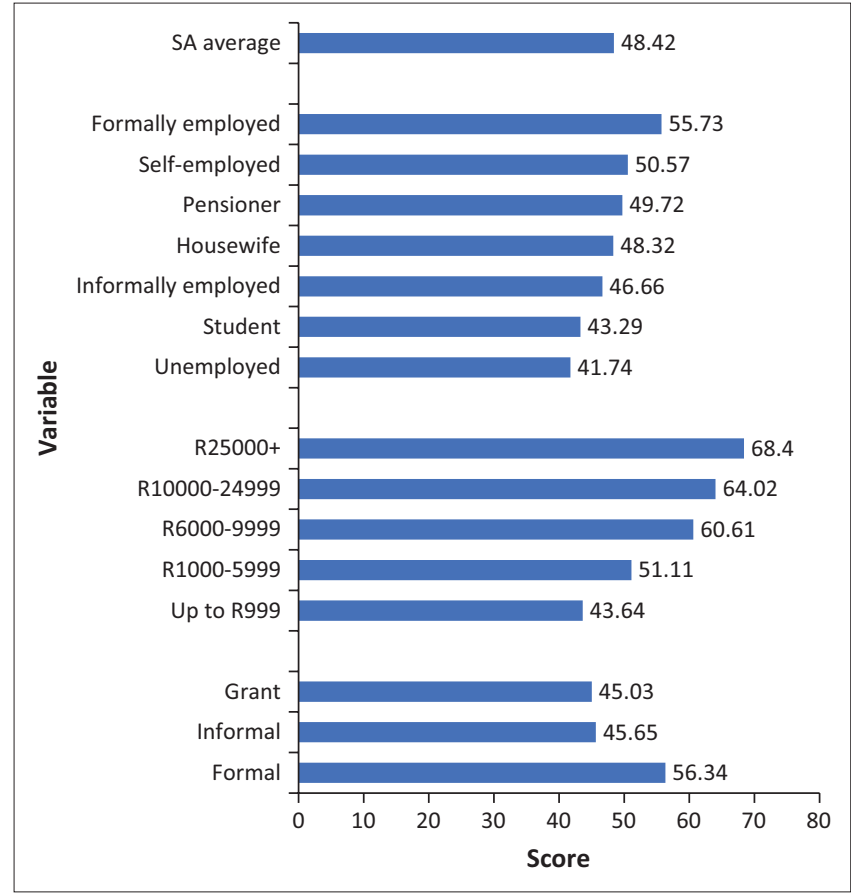

Note: The figure shows financial literacy scores by occupation, income and source of money. The data is weighted to be nationally representative, with weights benchmarked agains Statistics South Africa weights.

FIGURE 2: Financial literacy by occupation, income, and source of money.

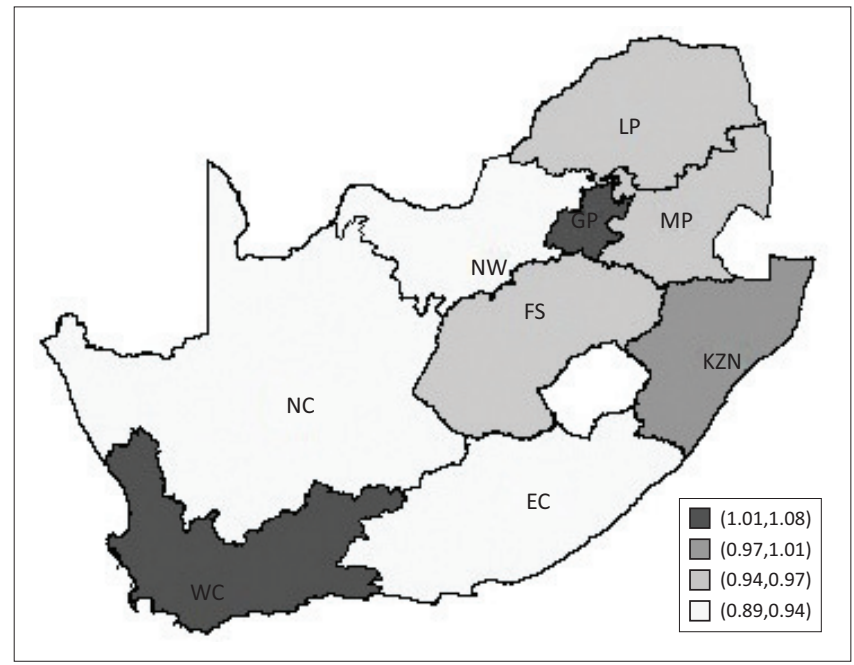

Note: The figure shows the relative distribution of financial literacy by province. The darke shades reflect higher financial literacy scores and they fade as the scores fall relative to the national average.

FIGURE 3: Provincial financial literacy relative to the national average.

products. ${ }^{11}$ Finally, financial literacy scores increase as income levels increase, a result similar to that found in most studies conducted elsewhere, reflecting either the increase in demand for financial products and services that require financial proficiency, or an increase in affordability of investment in acquiring financial literacy.

In terms of regional distribution, the Western Cape (52.4), Gauteng (52.5) and Kwa-Zulu Natal (48.9) have above

11.For instance, social welfare recipients in South Africa are paid through a bank account (see http://newsroom.mastercard.com/press-releases/ten-million-sassamastercard-cards-issued-to-south-africansocial-grant/), while this same group is targeted by moneylenders (see http://www.kayafm.co.za/moneylender-targetssocial-grant-beneficiaries/).
TABLE 3: Provincial ranking of financial literacy in South Africa.

\begin{tabular}{llc}
\hline Rank & Province & Average financial literacy score \\
\hline 1 & Gauteng & 52.5 \\
2 & Western Cape & 52.4 \\
3 & KwaZulu-Natal & 48.9 \\
4 & Limpopo & 46.8 \\
5 & Mpumalanga & 46.2 \\
6 & Free State & 46.2 \\
7 & North West & 45.6 \\
8 & Northern Cape & 45.6 \\
9 & Eastern Cape & 43.1 \\
\hline
\end{tabular}

Note: The table shows the average financial literacy scores per province and their ranking as a result thereof. The data is weighted to be nationally representative, with weights benchmarked against Statistics South Africa weights.

average scores while the Eastern Cape (43.1), North West (45.6) and Northern Cape (45.6) lag (see Figure 3 and Table 3). Provinces with higher levels of financial literacy are also associated with lower levels of poverty $\left(\mathrm{P}_{0} / \mathrm{P}_{1}=\right.$ $5.74 / 0.013,4.87 / 0.014$ and $22.12 / 0.068$ respectively) while those with the lowest literacy levels also rank among the poorest $\left(\mathrm{P}_{0} / \mathrm{P}_{1}=34.02 / 0.111,26.13 / 0.072\right.$ and $42.17 / 0.145$ respectively). ${ }^{12}$ These regional results also mimic the racial distribution in the country. For instance, white people, who have the highest scores, are concentrated in the Western Cape and Gauteng, while Indian/ Asian people, who follow closely, are concentrated in KwaZulu-Natal. On the other hand, the Eastern Cape has predominantly black people, while Northern Cape has predominantly mixed race people. These two population groups had the lowest financial literacy scores. In terms of economic activity, Gauteng and Kwa-Zulu Natal also happen to be the financial and business hubs of the country. Rural dwellers on average had lower financial literacy scores (46.24) than their urban counterparts (50.07). This finding is in line with those reported in almost all empirical studies on this subject. The difference is attributed partly to the high level of interaction in densely populated areas such as urban areas, which allows for the diffusion of knowledge (Klapper \& Panos 2011).

\section{The multivariate correlates of financial literacy}

The descriptive statistics show a positive association between financial literacy and several economic, demographic and geographic characteristics. However, there is a possible correlation between some of these characteristics themselves, for instance, province with race, and province with the rural dummy. To tease out the effect of each of these variables holding others constant, we conducted multivariate regression analysis. The dependent variable was the index of financial literacy, which was a continuous variable. Model 1 (Table 4) reports the estimated coefficients for a specification that includes all possible controls, as used in similar studies such as that by Lusardi and Mitchell (2014). Models 2 and 3 are specified to tease out the correlation between provinces and the rural-urban effect. Results reveal that compared to black people, the levels of financial literacy of white and Asian people are higher in all specifications and that this 12. $P_{0}$ is the head count poverty and $\mathrm{P}_{1}$ is the poverty gap. See Woolard and Leibbrandt (2009) on these and other provincial poverty measures. 
TABLE 4: Multivariate correlates of financial literacy in South Africa.

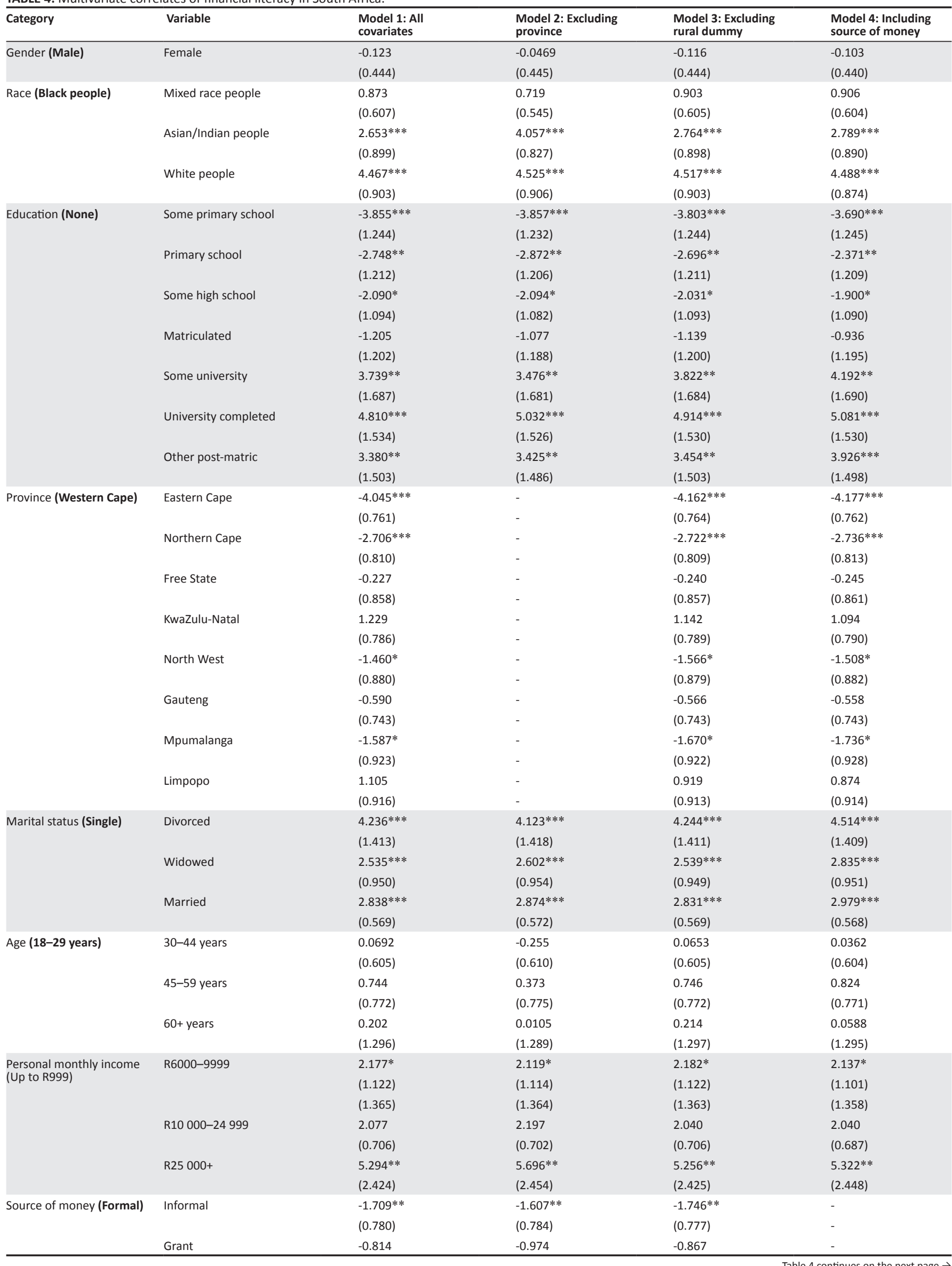


TABLE 4 (Continues...): Multivariate correlates of financial literacy in South Africa.

\begin{tabular}{|c|c|c|c|c|c|}
\hline Category & Variable & $\begin{array}{l}\text { Model 1: All } \\
\text { covariates }\end{array}$ & $\begin{array}{l}\text { Model 2: Excluding } \\
\text { province }\end{array}$ & $\begin{array}{l}\text { Model 3: Excluding } \\
\text { rural dummy }\end{array}$ & $\begin{array}{l}\text { Model 4: Including } \\
\text { source of money }\end{array}$ \\
\hline & & $(1.044)$ & $(1.045)$ & $(1.040)$ & - \\
\hline & Other & $-2.072 *$ & -1.923 & $-2.125^{*}$ & - \\
\hline & & $(1.250)$ & $(1.258)$ & (1.246) & - \\
\hline \multirow[t]{11}{*}{ Occupation (Pensioner) } & Formally employed & 1.745 & 1.882 & 1.755 & $2.275^{* *}$ \\
\hline & & (1.291) & (1.291) & (1.291) & $(1.157)$ \\
\hline & Housewife & -1.725 & -1.712 & -1.699 & -2.242 \\
\hline & & $(1.435)$ & $(1.442)$ & (1.434) & $(1.401)$ \\
\hline & Student & -1.624 & -1.637 & -1.600 & $-2.339 *$ \\
\hline & & $(1.397)$ & $(1.396)$ & $(1.397)$ & $(1.318)$ \\
\hline & Informally employed & -1.367 & -1.318 & -1.379 & -1.897 \\
\hline & & $(1.347)$ & $(1.348)$ & (1.348) & (1.259) \\
\hline & Self-employed & $2.050 *$ & $2.150 *$ & $2.073^{*}$ & $2.746 * *$ \\
\hline & & $(1.208)$ & $(1.205)$ & $(1.208)$ & $(1.148)$ \\
\hline & & (1.155) & (1.157) & (1.154) & (1.105) \\
\hline \multirow{4}{*}{$\begin{array}{l}\text { Banking history } \\
\text { (Currently banking) }\end{array}$} & Previously banked & $-7.389 * * *$ & $-7.178 * * *$ & $-7.409 * * *$ & $-7.462 * * *$ \\
\hline & & $(0.747)$ & $(0.757)$ & $(0.747)$ & $(0.746)$ \\
\hline & Never banked & $-9.490 * * *$ & $-9.429 * * *$ & $-9.516 * * *$ & $-9.436 * * *$ \\
\hline & & $(0.607)$ & $(0.606)$ & $(0.607)$ & $(0.601)$ \\
\hline \multirow[t]{2}{*}{ Constant } & - & $52.56 * * *$ & $51.85 * * *$ & $52.85 * * *$ & $52.22 * * *$ \\
\hline & - & (1.924) & $(1.830)$ & $(1.900)$ & (1.710) \\
\hline Mean VIF & - & 2.75 & 2.75 & 2.75 & 2.75 \\
\hline$N$ & - & 15692 & 15692 & 15692 & 15692 \\
\hline$R$-squared & - & 0.164 & 0.157 & 0.164 & 0.157 \\
\hline
\end{tabular}

$*, p<0.1 ; * *, p<0.05 ; * * *, p<0.01$.

Note: Robust standard errors are in parentheses and the base category in bold parentheses. Table reports ordinary least squares estimates of financial literacy based on the theoretical model specification. Model 1 includes all variables, Model 2 excludes the provinces and Model 3 excludes the rural dummy while retaining the provinces. Pairwise correlation test between income/ education and education/occupation detected no collinearity.

difference is statistically significant. Similarly, education levels above high school level (matric), income levels above R6000, as well as being divorced, married or widowed are positively correlated with higher financial literacy scores. Significant racial influences have been reported by Bumcrot et al. (2011) in the USA, Crossan et al. (2011) in New Zealand, Alessie, van Rooij and Lusardi (2011) in the Netherlands, Dragan (2011) in Bosnia and Herzegovina, and Xu and Zia (2012) globally. The effect of marital status might in part reflect the nature of marriage contracts in the country or, as Hsu (2011) argues, strategic acquisition of financial literacy following separation from or the death of a life partner. ${ }^{13}$ A similar effect of education and income has been reported by Behrman et al. (2010). The argument is that individuals in higher income brackets can afford the cost of acquiring financial literacy and thus seek more financial knowledge to better manage their financial wealth.

Although men were found to have higher levels of financial literacy than women, this variable is not statistically significant. This result can be compared to a similar finding reported by Bucher-Koenen and Lusardi (2011) for East Germany, where gender was not significant in relation to an individual's financial literacy level. Furthermore, despite evidence of the inverted U-shape pattern often seen in the relationship between age and financial literacy, the estimation results show no statistical significance of the age variable.

13.In South Africa, those married in community of property share equally in the wealth of the partnership. This includes financial obligations such as debt and investments. Thus married individuals are more motivated to learn about finances or to fall victim to the financial mistakes of their spouses - but only if they are married under this regime.
This result suggests that either age does not influence financial literacy in a South African setting, or that financial literacy related challenges cut across age groups.

Compared to the Western Cape, residing in the Eastern Cape, Mpumalanga, North West or Northern Cape has a significantly negative influence on the financial literacy score. However, rural or urban dwelling has no significant effect. This result does not change even when we exclude provinces (Model 2, Table 4). Excluding the rural-urban dummy while retaining provinces increases the effect of provinces slightly though. This rural-urban result is rather unusual when compared to other studies; however, we believe that the effect is probably captured at the provincial level. Indeed, Bumcrot et al. (2011) controlled for residence at state level in the USA and found significant results. This interesting rural-urban result shows the importance of the multivariate analysis.

These regression results generally confirm some of the correlations revealed in the descriptive statistics and they are generally similar to global patterns (see Lusardi \& Mitchell 2014; Xu \& Zia 2012). In particular, they point to the significance of characteristics such as race, education and region (province).

Yet, several studies have found geographical location to statistically influence financial literacy more than economic and demographic characteristics. To isolate these effects, we followed Raudenbush and Bryk (2002) and estimated a 
hierarchical linear model. In this approach, the interest is in the incremental explained variance between groups of variables. Thus, financial literacy scores were regressed first on demographic characteristics and then geographical location was added at the second level. The demographic variables considered were education, gender, income, marital status and race, as these turned out to be statistically significant in the basic ordinary least squares, while the geographical characteristics included all provinces. Except for gender, which is a binary variable, all other regressors were categorical variables for which dummy variables were created..$^{14}$

Table 5 reports the variation in financial literacy accounted for by the two subgroups of variables. Demographic variables accounts for $10 \%$ of the variation, while the inclusion of province contributes only $0.7 \%$ additional predictive power. The implication of these results is that the significance of the provincial variable, at least for three of the nine provinces, is likely to be driven by the demographic and socio-economic differences between the provinces. Thus, any attempt to address the provincial financial literacy gap would only be effective if it is complemented by initiatives that address the demographic differences across provinces.

What is evident in this study is that there are significant differences in the financial literacy levels of South Africans between and within demographic and social economic categories. The patterns observed resonate with global findings both in developed and in developing economies. This provides reassurance that the measure we have constructed captures the duality of the country.

\section{Conclusion}

In this article, we provide a benchmark profile of financial literacy in South Africa following financial sector transformation in the country and increasing innovation in the financial sector. In the absence of a standard definition and measure of financial literacy, we use observational data and a quantitative approach to construct a financial literacy measure in the form of a financial literacy index. The variables used in the construction of the financial literacy measure are in line with the microeconomic framework of the financial behaviour and consumption-saving decision-making process of an individual. Our approach differs from approaches like the 'Big Three' and the subsequent 'Big Five' used in earlier studies, which focus on knowledge of interest rates, inflation and risk diversification as being synonymous to financial literacy. We also differ from studies that use the outcomebased approach especially in developing countries, where

\begin{tabular}{lllll}
\multicolumn{5}{l}{ TABLE 5: Demographic versus geographic variation in financial literacy. } \\
\hline Model & Variables & $\boldsymbol{R}^{2}$ Change & $\boldsymbol{F}$ Change & $\boldsymbol{p}$ \\
\hline 01 & Demographics & 0.103 & 60.878 & 0.0000 \\
02 & Provinces & 0.007 & 16.244 & 0.0000 \\
\hline
\end{tabular}

Note: Demographic variables include education, gender, income, marital status and race.

14.This approach was used by Bumcrot et al. (2011) to isolate the effect of the demographic variables from the geographical variations in financial literacy in the USA. the possession of a formal financial product is considered to be a measure of financial proficiency. We argue that such an outcome-based approach might instead capture the extent of financial access, which in the South African context is plausible given the financial sector transformation process of the early 2000s.

The results presented in this article reveal a national average financial literacy score of 48.4, and dramatic differences in financial literacy by key characteristics, using pooled data for the period 2005-2009. Below average financial literacy is common among women, young adults (including students), and individuals with less than matric (high school) education, black people, the unemployed, and rural dwellers. While urban dwellers exhibit above average financial literacy, this variable is not statistically significant in the case of South Africa. Similarly, even though there is evidence of an inverted U-shape in the association between age and financial literacy, age is not a statistically significant correlate. Education, income, geographical location, marital status and race are the significant contributors to the financial literacy of South Africans. However, the significance of geographical location is outweighed by the demographic characteristics. This implies that provincial variation in financial literacy can change in line with changes in these characteristics, resulting from provincial migrations and changes in economic activities, for example.

In examining what drives the financial literacy levels observed in this study, we find that the scores are higher in the financial knowledge domain than in the financial capability domain. In other words, financial concepts or terms are well engrained in the minds of South Africans, but positive financial behaviour is lacking. According to the capability theory of Nussbaum and Sen (1993) and Hilgert, Hogarth and Beverly (2003), this behaviour can be attributed to a potentially unsupportive external economic environment within which the individual has to convert knowledge into practice. In a South African environment, an example might be the lack of transparency of financial institutions in terms of bank fees and charges, which deters potential users of financial products. Additionally, the existence of credit facilities can have the unintended consequence of not saving regularly. Another possible explanation, borrowed from behavioural economics, pertains to psychological biases that underlie differences in financial capabilities over and above financial knowledge. De Meza, Irlenbusch and Reyniers (2008) identify procrastination, aversion to loss and regret, status quo bias and mental accounting as some of the biases. However, we could not identify any of these behavioural variables in our data and many of them might be caused by socioeconomic circumstances. For example, risk aversion might be induced by poverty. Thus, notwithstanding these biases, these results provide a baseline for financial education programmes. Indeed, positive behavioural aspects can be weaved into such programmes. 
The novelty of these results lies in appropriately defining financial literacy within the context of South Africa and using existing surveys to construct a country-specific measure. Given the prohibitive cost of financial literacy tailored surveys and experiments, this study provides an alternative and cost-effective approach for countries where such surveys exist. Furthermore, as most studies tend to be focused on a particular financial product (for instance credit, investment or insurance), our approach provides a generic measure that can be tested across financial product categories. This is not far-fetched considering that crossproduct holding is common practice for consumers of financial products and services.

\section{Acknowledgements}

E.L.N. acknowledges participants at the African Econometrics Society Conference in 2014 for their insightful comments, and funding from the Carnegie Foundation and the National Research Foundation. M.L. acknowledges the Research Chairs Initiative of the Department of Science and Technology and the National Research Foundation for funding his work as the NRF/DST Research Chair in Poverty and Inequality. E.L.N.'s PhD was funded by scholarships from Carnegie and the SARChI: Poverty and Inequality Research.

\section{Competing interests}

The authors declare that they have no financial or personal relationships that may have inappropriately influenced them in writing this article.

\section{Authors' contributions}

This article is based on a chapter from E.L.N.'s PhD thesis, for which M.L. acted as supervisor. Both authors worked together to prepare the journal article, with E.L.N. contributing all data analysis and M.L. providing the contextualisation of the project and editing of the article.

\section{References}

Alessie, R., Van Rooij, M. \& Lusardi, A., 2011, Financial literacy, retirement preparation and pension expectations in the Netherlands, CeRP Working Papers, Center for Research on Pensions and Welfare Policies, Turin.

Atkinson, A., Mckay, S., Collard, S. \& Kempson, E., 2007, 'Levels of financial capability in the UK', Public Money and Management 27(1), 29-36. https://doi.org/10.1111/ j.1467-9302.2007.00552.x

Beal, D. \& Delpachitra, S., 2003, 'Financial literacy among Australian University students', Economic Papers 22(1), 65-78.

Behrman, J.R., Mitchell, O.S., Soo, C. \& Bravo, D., 2010, Financial literacy, schooling, and wealth accumulation, National Bureau of Economic Research, Cambridge, MA.

Bucher-Koenen, T. \& Lusardi, A., 2011, Financial literacy and retirement planning in Germany, CeRP Working Papers, Center for Research on Pensions and Welfare Policies, Turin.

Bumcrot, C.B., Lin, J. \& Lusardi, A., 2011, The geography of financial literacy, Numeracy 6(2), 1-16. http://dx.doi.org/10.5038/1936-4660.6.2.2

Chen, H. \& Volpe, R.P., 2002, 'Gender differences in personal financial literacy among college students', Financial Services Review 11, 4

Cohen, M. \& Young, P., 2007, 'Using micro insurance and financial education to protect and accumulate assets', in C.O.N. Moser (ed.), Reducing global poverty: The case for asset accumulation, p. 305, The Brookings Institution Press, Washington, DC.
Cole, S., Sampson, T. \& Zia, B., 2011, 'Prices or knowledge: What drives demand for financial services in emerging markets?', Journal of Finance 66(6), 1933-1967. https://doi.org/10.1111/j.1540-6261.2011.01696.x

Crossan, D., Feslier, D. \& Hurnard, R., 2011, Financial literacy and retirement planning in New Zealand, CeRP Working Papers, Center for Research on Pensions and Welfare Policies, Turin.

De Meza, D., Irlenbusch, B. \& Reyniers, D., 2008, Financial capability: A behavioural economics perspective, London: Financial Services Authority.

Dragan, B., 2011, Financial literacy in Bosnia and Herzegovina: Analytical report, World Bank, Washington, DC.

Erikson, E.H., 1980, 'Elements of a psychoanalytic theory of psychosocial development', in S.I. Greenspan \& G.H. Pollack (eds.), The course of life: Psychoanalytic contributions towards understanding personality development, Vol. I: Infancy and early childhood, National Institute of Mental Health, Washington, DC.

Fornero, E. \& Monticone, C., 2011, 'Financial literacy and pension plan participation in Italy', Journal of Pension Economics and Finance 10(4), 547-564. https://doi. org/10.1017/S1474747211000473

Friedman, M., 1957, 'The permanent income hypothesis', in M. Friedman, A theory of the consumption function, pp. 20-37, Princeton University Press, NJ.

Garcia, M.J.R., 2013, 'Financial education and behavioural finance: New insights into the role of information in financial decisions', Journal of Economic Surveys 27, 297-315. https://doi.org/10.1111/j.1467-6419.2011.00705.x

Gine, X., Menand, L., Townsend, R. \& Vickery, J., 2010, Micro insurance: A case study of the Indian rainfall index insurance market, World Bank Policy Research Working Paper Series, The World Bank, Washington, DC.

Goldhaber, D.E., 2000, Theories of human development: Integrative perspectives, Mayfield Publishing, Mountain View, CA.

Gorbachev, O. \& Luengo-Prado, M.J., 2016, 'The credit card puzzle: The role of preferences, credit risk and financial literacy', Working Paper 2016 Series-16-6,
Federal Reserve Bank of Boston, Boston, MA, viewed n.d., from https://www. Federal Reserve Bank of Boston, Boston, MA, viewed n.d., from https://www.
bostonfed.org/publications/research-department-working-paper/2016/thecredit-card-debt-puzzle-the-role-of-preferences-credit-risk-and-financial-literacy. aspx

Hilgert, M.A., Hogarth, J.M. \& Beverly, S.G., 2003, 'Household financial management: The connection between knowledge and behaviour', Federal Reserve Bulletin 89(7), 309-322.

Hsu, J., 2011, Aging and strategic learning: The impact of spousal incentives on financial literacy, Networks Financial Institute, Working Paper 2011-WP-06, Indiana State University, Terre Haute, IN, viewed n.d., from https://www.finmark. org.za/finscope/

Hung, A.A., Parker, A.M. \& Yoong, J.K., 2009, 'Defining and measuring financial literacy', RAND Working Paper WR-708, RAND Corporation, Santa Monica, CA.

Huston, S.J., 2010, 'Measuring financial literacy', Journal of Consumer Affairs 44(2), 296-316. https://doi.org/10.1111/j.1745-6606.2010.01170.x

Jappelli, T. \& Padula, M., 2011, Investment in financial literacy and savings decisions, Centre for Studies in Economics and Finance, Working Paper No. 272, University of Naples Frederico II, Naples.

Johnson, E. \& Sherraden, M.S., 2006, 'From financial literacy to financial capability among youth', Journal of Sociology and Social Welfare 34(3), Art. 7.

Kempson, E.C.S. \& Moore, N., 2005, Measuring financial capability: An exploratory study, Consumer Research Report 37, Financial Services Authority, London.

King, R.G. \& Levine, R., 1993, 'Finance and growth: Schumpeter might be right', The Quarterly Journal of Economics, 108(3), 717-737. https://doi. org/10.2307/2118406

Klapper, L. \& Panos, G., 2011, 'Financial literacy and retirement planning: The Russian case', Journal of Pension Economics and Finance 10(4), 599-618. https://doi. org/10.1017/S1474747211000503

Lusardi, A., 2008a, Household saving behavior: The role of financial literacy, information, and financial education programs, NBER Working Paper 13824 National Bureau of Economic Research, Cambridge, MA.

Lusardi, A., 2008b, Financial literacy: An essential tool for informed consumer choice?, NBER Working Paper 14084, National Bureau of Economic Research, Cambridge, MA.

Lusardi, A. \& Mitchell, O.S., 2007, 'Baby boomers' retirement security: The role of planning, financial literacy and housing wealth', Journal of Monetary Economics 54, 205-224. https://doi.org/10.1016/j.jmoneco.2006.12.001

Lusardi, A. \& Mitchell, O.S., 2011a, 'The outlook for financial literacy', in O.S Mitchell \& A. Lusardi (eds.), Financial literacy: Implications for retirement security and the financial marketplace, pp. 181-205, Oxford University Press, Oxford.

Lusardi, A. \& Mitchell, O.S., 2011b, Financial literacy around the world: An overview, CeRP Working Papers, Center for Research on Pensions and Welfare Policies, Turin.

Lusardi, A. \& Mitchell, O.S., 2014, 'The economic importance of financial literacy: Theory and evidence', Journal of Economic Literature 52(1), 5-44. https://doi. org/10.1257/jel.52.1.5

Lusardi, A., Mitchell, O.S. \& Curto, V., 2009, Financial literacy among the young: Evidence and implications for consumer policy, NBER Working Paper No. 15352, National Bureau of Economic Research, Cambridge, MA.

Lusardi, A. \& Tufano, P., 2008, 'Debt literacy, financial experiences, and overindebtedness', NBER Working Paper No. 14808, National Bureau of Economic Research, Cambridge, MA.

Mandell, L., 1997, Our vulnerable youth: The financial literacy of American 12th graders, Jump\$tart Coalition for Personal Financial Literacy, Washington, DC. 
Mandell, L., 2007, 'Financial literacy of high school students', in J.J. Xiao (ed.) Handbook of Consumer Finance Research, pp. 163-183, Springer, New York, NY.

Markow, D. \& Bagnaschi, K., 2005, What American teens know about economics, National Council on Economic Education, New York, NY.

Miller, M., Godfrey, N., Levesque, B., \& Stark, E., 2009, 'The case for financial literacy in developing countries: Promoting access to finance by empowering consumers', OECD, World Bank, DFID, CGAP joint note, World Bank, Washington, DC.

Modigliani, F. \& Brumberg, R., 1954, 'Utility analysis and the consumption function: An interpretation of cross-section data', in K.K. Kurihara (ed.), Post-Keynesian economics, pp. 388-436, Rutgers University Press, New Brunswick, NJ.

Muradoglu, G. \& Harvey, N., 2012, 'Behavioural finance: The role of psychological factors in financial decisions', Review of Behavioural Finance 4(2), 68-80. https:// doi.org/10.1108/19405971211284862

Nussbaum, M.C. \& Sen, A.K. (eds.), 1993, The quality of life, Clarendon Press, Oxford.

Organisation for Economic Co-operation and Development (OECD), 2005, 'Improving financial literacy: Analysis of issues and policies', Financial Market Trends, (11)2, 111-123. http://dx.doi.org/10.1787/fmt-v2005-art11-en
Pavlov, I., 1960, Conditioned reflexes: An investigation of the physiological activity of the Cerebral Cortex, trans, Dover Publications, New York, NY.

Raudenbush, S.W. \& Bryk, A.S., 2002, Hierarchical linear models: Applications and data analysis methods, 2 nd edn., Sage, Thousand Oaks, CA.

Robson, J. \& Ladner, S., 2006, Asset-based approaches to settlement services in Canada, Discussion paper, System for Electronic Disclosures by Insiders (SEDI) Toronto.

Tran, N. \& Yun, T.S., 2004, 'TYM's mutual assistance fund: Vietnam good and bad practices in micro insurance case studies', CGAP Working Group on Micro Insurance, CGAP, Washington, DC.

Vyas, S. \& Kumaranayake, L., 2006, 'Constructing socio-economic status indices: How to use principal components analysis', Health Policy and Planning 21(6), 459-468. https://doi.org/10.1093/heapol/czl029

Woolard, I. \& Leibbrandt, M., 2009, Measuring poverty in South Africa, Development Policy Research Unit, University of Cape Town, Cape Town.

Xu, L. \& Zia, B., 2012, Financial literacy around the World: An overview of the evidence with practical suggestions for the way forward, Policy Research Working Paper 6107, World Bank, Washington, DC. 


\section{Appendix 1}

TABLE 1-A1: Conceptual definitions of financial literacy.

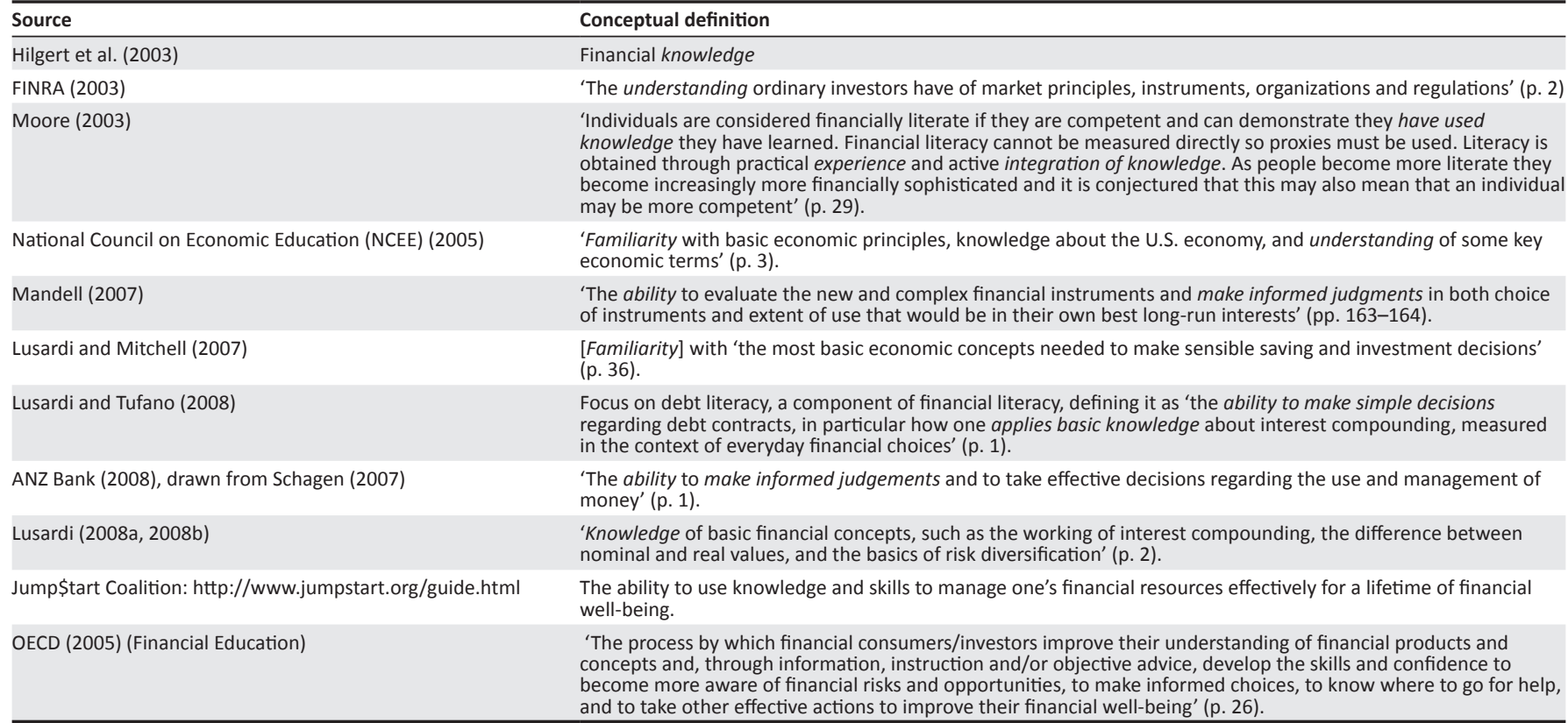

Source: Adapted from Hung, A.A., Parker, A.M. \& Yoong, J.K., 2009, ‘Defining and measuring financial literacy', RAND Working Paper WR-708, RAND Corporation, Santa Monica, CA 


\section{Appendix 2}

TABLE 1-A2: Average scores in the financial knowledge domain (pooled data).

\begin{tabular}{|c|c|c|c|c|}
\hline$\overline{\text { Category }}$ & Variable & Mean & SD & Valid $N$ \\
\hline Sample & - & 5.14 & 2.07 & 18717 \\
\hline \multirow[t]{2}{*}{ Gender } & Male & 5.22 & 2.07 & 9319 \\
\hline & Female & 5.07 & 2.06 & 9398 \\
\hline \multirow[t]{4}{*}{ Race } & Black people & 4.74 & 1.94 & 10333 \\
\hline & Mixed race people & 5.68 & 1.86 & 3507 \\
\hline & Indian people & 6.38 & 1.91 & 1397 \\
\hline & White people & 7.09 & 1.74 & 3457 \\
\hline \multirow[t]{8}{*}{ Education } & No formal education & 4.56 & 1.73 & 558 \\
\hline & Some primary education & 4.36 & 2.03 & 1145 \\
\hline & Primary school completed & 4.62 & 1.86 & 1370 \\
\hline & Some high school education & 4.80 & 1.99 & 7099 \\
\hline & Matriculated & 5.41 & 2.04 & 5545 \\
\hline & Some university education & 6.02 & 1.95 & 653 \\
\hline & University completed & 6.78 & 1.77 & 1192 \\
\hline & Any other post-matric qualification & 6.42 & 1.93 & 1155 \\
\hline \multirow[t]{4}{*}{ Age category } & $18-29$ years & 4.81 & 2.01 & 5851 \\
\hline & $30-44$ years & 5.22 & 2.06 & 6490 \\
\hline & $45-59$ years & 5.52 & 2.02 & 3970 \\
\hline & $60+$ years & 5.49 & 2.15 & 2352 \\
\hline \multirow[t]{9}{*}{ Province } & Eastern Cape & 5.06 & 1.96 & 2274 \\
\hline & Free State & 4.83 & 2.08 & 1724 \\
\hline & Gauteng & 5.57 & 2.02 & 3042 \\
\hline & KwaZulu-Natal & 5.10 & 2.04 & 2815 \\
\hline & Mpumalanga & 4.49 & 2.10 & 1611 \\
\hline & Northern Province/Limpopo & 4.48 & 2.05 & 1581 \\
\hline & Northern Cape & 5.24 & 1.96 & 1476 \\
\hline & North West & 4.77 & 1.93 & 1740 \\
\hline & Western Cape & 5.89 & 2.03 & 2454 \\
\hline \multirow[t]{2}{*}{ Area } & Rural & 4.78 & 2.00 & 6346 \\
\hline & Urban & 5.41 & 2.07 & 12371 \\
\hline \multirow[t]{4}{*}{ Marital status } & Single & 4.80 & 2.00 & 8177 \\
\hline & Divorced & 5.84 & 1.97 & 568 \\
\hline & Widowed & 5.24 & 2.06 & 1493 \\
\hline & Married/living with partner & 5.56 & 2.08 & 8479 \\
\hline \multirow[t]{5}{*}{ Source of money } & Formal & 5.91 & 1.98 & 5374 \\
\hline & Informal & 4.80 & 2.03 & 5839 \\
\hline & Grant & 4.71 & 2.00 & 2658 \\
\hline & Other & 6.12 & 2.21 & 1200 \\
\hline & None & 4.41 & 2.05 & 1799 \\
\hline \multirow[t]{5}{*}{ Personal income } & Up to R999 & 4.72 & 1.91 & 8407 \\
\hline & 1000-5999 & 5.18 & 2.03 & 5509 \\
\hline & 6000-9999 & 6.56 & 1.76 & 1014 \\
\hline & $10000-24999$ & 7.23 & 1.59 & 730 \\
\hline & R25 000+ & 7.53 & 1.65 & 81 \\
\hline \multirow[t]{7}{*}{ Occupation } & Pensioner & 5.46 & 2.12 & 2469 \\
\hline & Formally employed & 5.78 & 1.96 & 5946 \\
\hline & Housewife & 5.50 & 2.16 & 945 \\
\hline & Student & 4.68 & 1.98 & 1252 \\
\hline & Informally employed & 4.76 & 1.97 & 1546 \\
\hline & Self-employed & 5.33 & 1.82 & 2094 \\
\hline & Unemployed & 4.48 & 2.04 & 4287 \\
\hline \multirow[t]{3}{*}{ Banking history } & Currently banking & 5.60 & 2.03 & 12226 \\
\hline & Previously banked & 4.92 & 1.84 & 1728 \\
\hline & Not banked & 4.35 & 1.95 & 4763 \\
\hline
\end{tabular}

$\mathrm{SD}$, standard deviation.

Note: The table shows the average number of questions answered in the affirmative in the financial knowledge domain, decomposed by the socio-economic and demographic characteristics of the respondents, using the pooled dataset. The data is weighted and thus the responses are nationally representative.

\section{Appendix 3}

TABLE 1-A3: Average scores in the financial capability domain (pooled data).

\begin{tabular}{|c|c|c|c|}
\hline Category & Variable & Mean & Valid $N$ \\
\hline Sample & - & 3.05 & 18717 \\
\hline \multirow[t]{2}{*}{ Gender } & Male & 3.09 & 9319 \\
\hline & Female & 3.01 & 9398 \\
\hline \multirow[t]{4}{*}{ Population group } & Black people & 2.95 & 10333 \\
\hline & Mixed race people & 2.97 & 3507 \\
\hline & Indian people & 3.64 & 1397 \\
\hline & White people & 3.65 & 3457 \\
\hline \multirow[t]{8}{*}{ Education } & No formal education & 2.46 & 558 \\
\hline & Some primary education & 2.61 & 1145 \\
\hline & Primary school completed & 2.62 & 1370 \\
\hline & Some high school education & 2.85 & 7099 \\
\hline & Matriculated & 3.27 & 5545 \\
\hline & Some university & 3.87 & 653 \\
\hline & University completed & 4.02 & 1192 \\
\hline & Any other post-matric qualification & 3.64 & 1155 \\
\hline \multirow[t]{4}{*}{ Age category } & $18-29$ years & 2.99 & 5851 \\
\hline & $30-44$ years & 3.11 & 6490 \\
\hline & $45-59$ years & 3.12 & 3970 \\
\hline & $60+$ years & 3.00 & 2352 \\
\hline \multirow[t]{9}{*}{ Province } & Eastern Cape & 2.53 & 2274 \\
\hline & Free State & 3.08 & 1724 \\
\hline & Gauteng & 3.37 & 3042 \\
\hline & KwaZulu-Natal & 3.03 & 2815 \\
\hline & Mpumalanga & 3.18 & 1611 \\
\hline & Limpopo & 2.96 & 1581 \\
\hline & Northern Cape & 2.96 & 1476 \\
\hline & North West & 2.92 & 1740 \\
\hline & Western Cape & 3.22 & 2454 \\
\hline \multirow[t]{2}{*}{ Area } & Rural & 2.89 & 6346 \\
\hline & Urban & 3.18 & 12371 \\
\hline \multirow[t]{4}{*}{ Marital status } & Single & 2.94 & 8177 \\
\hline & Divorced & 3.03 & 568 \\
\hline & Widowed & 2.87 & 1493 \\
\hline & Married/living with partner & 3.25 & 8479 \\
\hline \multirow[t]{4}{*}{ Sources of money } & Formal & 3.60 & 5374 \\
\hline & Informal & 2.99 & 5839 \\
\hline & Grant & 2.75 & 2658 \\
\hline & None & 2.47 & 1799 \\
\hline \multirow[t]{5}{*}{ Personal monthly income } & Up to R999 & 2.64 & 8407 \\
\hline & R1000-5999 & 3.43 & 5509 \\
\hline & R6000-9999 & 3.84 & 1014 \\
\hline & R10 000-24999 & 3.77 & 730 \\
\hline & R25 000+ & 4.32 & 81 \\
\hline \multirow[t]{7}{*}{ Occupation } & Pensioner & 2.97 & 2469 \\
\hline & Formally employed & 3.58 & 5946 \\
\hline & Housewife & 2.93 & 945 \\
\hline & Student & 2.90 & 1252 \\
\hline & Informally employed & 3.02 & 1546 \\
\hline & Self-employed & 2.97 & 2094 \\
\hline & Unemployed & 2.67 & 4287 \\
\hline \multirow[t]{3}{*}{ Banking history } & Currently banking & 3.49 & 12226 \\
\hline & Previously banked & 2.53 & 1728 \\
\hline & Not banked & 2.42 & 4763 \\
\hline
\end{tabular}

Note: The table shows pooled weighted responses by respondents to the questions in the capability domain. The weights used are in line with those used by Statistics South Africa for the period under review and, as such, the results are nationally representative. 


\section{Appendix 4}
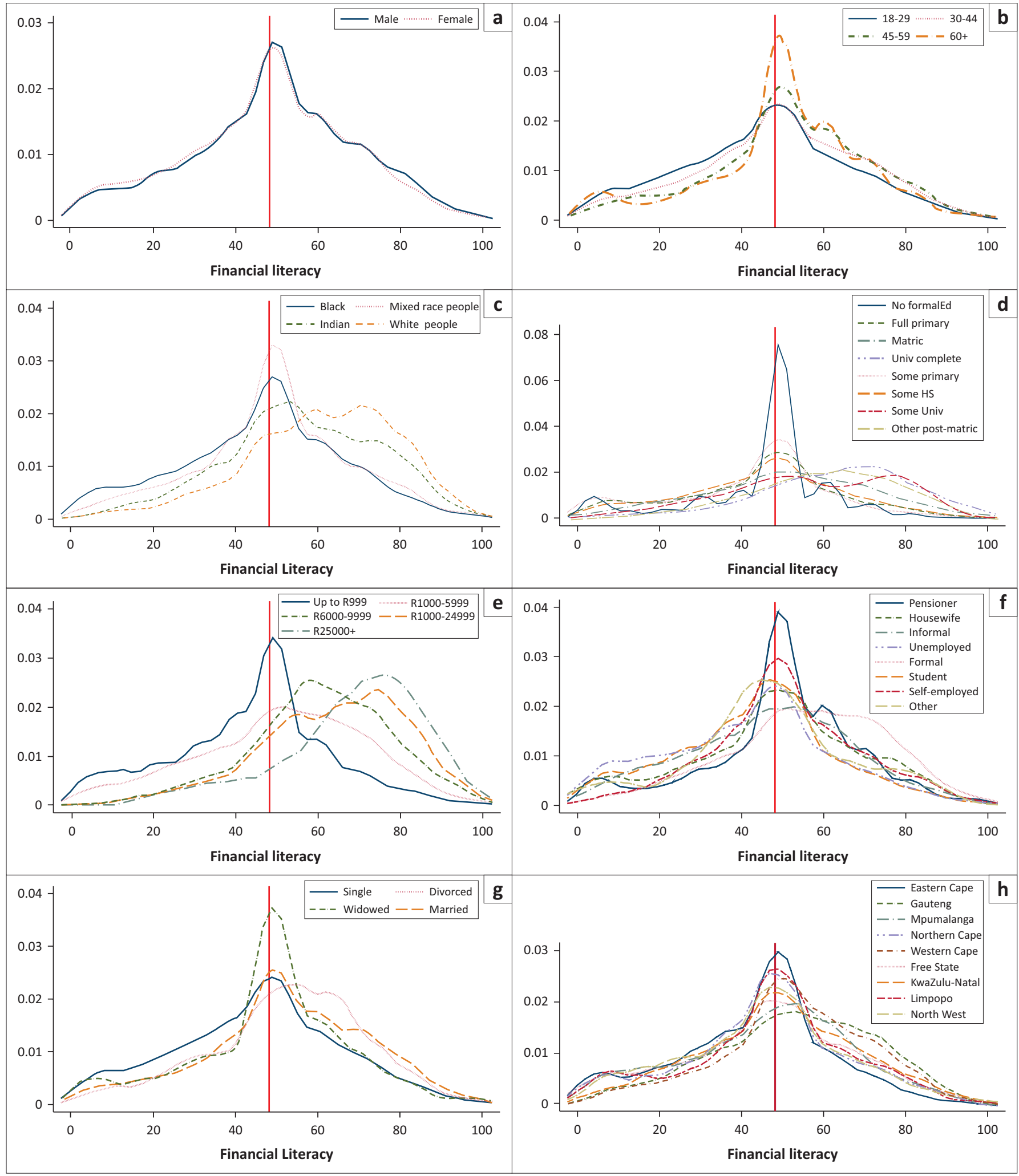

Notes: The data is weighted to be nationally representative. The vertical line shows the national average of 48.4 out of 100 .

FIGURE 1-A4: The distribution of financial literacy scores in South Africa by the individual's characteristics (pooled sample): (a) Financial literacy by gender, (b) age group, (c) race, (d) education level, (e) income level, (f) occupation, (g) marital status, (h) province, (i) geo-area and (j) banking history. 


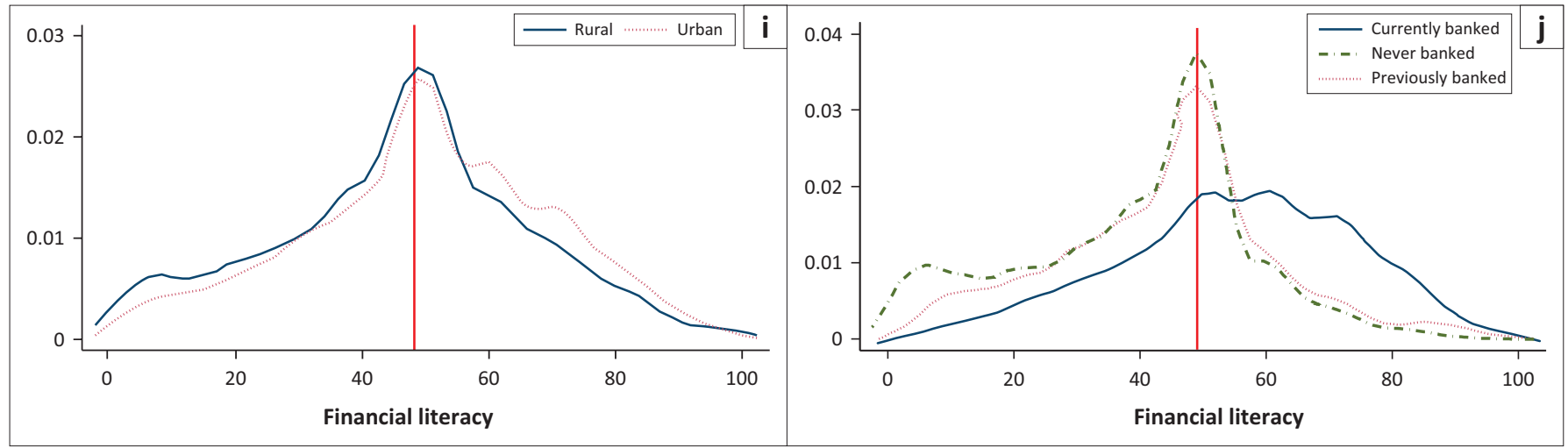

Notes: The data is weighted to be nationally representative. The vertical line shows the national average of 48.4 out of 100 .

FIGURE 1-A4 (Continues...): The distribution of financial literacy scores in South Africa by the individual's characteristics (pooled sample): (a) Financial literacy by gender, (b) age group, (c) race, (d) education level, (e) income level, (f) occupation, (g) marital status, (h) province, (i) geo-area and (j) banking history. 


\section{Appendix 5}

TABLE 1-A5: Decomposition of average scores of financial literacy.

\begin{tabular}{|c|c|c|c|}
\hline Category & Variable & Mean & Valid $N$ \\
\hline SA average & - & 48.42 & 18717 \\
\hline \multirow[t]{2}{*}{ Gender } & Male & 49.02 & 9319 \\
\hline & Female & 47.87 & 9398 \\
\hline \multirow[t]{4}{*}{ Population group } & Black people & 46.19 & 10333 \\
\hline & Mixed race people & 49.19 & 3507 \\
\hline & Indian people & 55.83 & 1397 \\
\hline & White people & 60.86 & 3457 \\
\hline \multirow[t]{8}{*}{ Education } & No formal education & 45.71 & 558 \\
\hline & Some primary education & 42.40 & 1145 \\
\hline & Primary school completed & 44.33 & 1370 \\
\hline & Some high school education & 45.20 & 7099 \\
\hline & Matriculated & 50.47 & 5545 \\
\hline & Some university & 57.46 & 653 \\
\hline & $\begin{array}{l}\text { Any other post-matric } \\
\text { qualification }\end{array}$ & 58.73 & 1155 \\
\hline & University & 63.02 & 1192 \\
\hline \multirow[t]{4}{*}{ Age category } & $18-29$ years & 45.79 & 5851 \\
\hline & $30-44$ years & 49.45 & 6490 \\
\hline & $45-59$ years & 51.39 & 3970 \\
\hline & $60+$ years & 50.02 & 2352 \\
\hline \multirow[t]{9}{*}{ Province } & Eastern Cape & 43.12 & 2274 \\
\hline & Northern Cape & 45.58 & 1476 \\
\hline & North West & 45.63 & 1740 \\
\hline & Free State & 46.19 & 1724 \\
\hline & Mpumalanga & 46.21 & 1611 \\
\hline & Limpopo & 46.86 & 1581 \\
\hline & KwaZulu-Natal & 48.93 & 2815 \\
\hline & Gauteng & 52.45 & 3042 \\
\hline & Western Cape & 52.46 & 2454 \\
\hline \multirow[t]{2}{*}{ Area } & Rural & 46.24 & 6346 \\
\hline & Urban & 50.07 & 12371 \\
\hline \multirow[t]{4}{*}{ Marital status } & Single & 45.36 & 8166 \\
\hline & Divorced & 52.69 & 568 \\
\hline & Widowed & 48.62 & 1493 \\
\hline & Married & 52.45 & 8467 \\
\hline \multirow[t]{3}{*}{ Source of money } & Formal & 56.34 & 5374 \\
\hline & Informal & 45.65 & 5839 \\
\hline & Grant & 45.03 & 2658 \\
\hline \multirow{5}{*}{$\begin{array}{l}\text { Personal monthly } \\
\text { income }\end{array}$} & Up to R999 & 43.64 & 8407 \\
\hline & R1000-5999 & 51.11 & 5509 \\
\hline & R6000-9999 & 60.61 & 1014 \\
\hline & R10 000-24 999 & 64.02 & 730 \\
\hline & R25 000+ & 68.40 & 81 \\
\hline \multirow[t]{7}{*}{ Occupation } & Unemployed & 41.74 & 4287 \\
\hline & Student & 43.29 & 1252 \\
\hline & Informally employed & 46.66 & 1546 \\
\hline & Housewife & 48.32 & 945 \\
\hline & Pensioner & 49.72 & 2469 \\
\hline & Self-employed & 50.57 & 2094 \\
\hline & Formally employed & 55.73 & 5946 \\
\hline \multirow[t]{3}{*}{ Banking history } & Currently banking & 54.06 & 12211 \\
\hline & Previously banked & 42.99 & 1723 \\
\hline & Never banked & 39.70 & 4760 \\
\hline
\end{tabular}

Notes: The table shows the decomposition of the average financial literacy score by sociodemographic characteristics of South Africans. The data is weighted to be nationally representative. Weights are benchmarked against Statistics South Africa weights. 